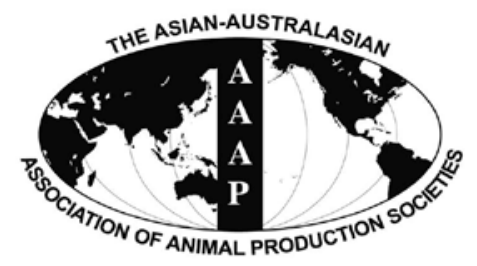

Asian-Aust. J. Anim. Sci.

Vol. 25, No. 1 : 104 - 113

January 2012

www.ajas.info

http://dx.doi.org/10.5713/ajas.2011.11052

\title{
Energy and Standardized Ileal Amino Acid Digestibilities of Chinese Distillers Dried Grains, Produced from Different Regions and Grains Fed to Growing Pigs*
}

\author{
P. C. Xue, B. Dong, J. J. Zang, Z. P. Zhu and L. M. Gong** \\ State Key Laboratory of Animal Nutrition, China Agricultural University, \\ No. 2 Yuanmingyuan West Road, Beijing, 100193, China
}

\begin{abstract}
Two experiments were conducted to determine the digestibility of crude protein (CP), amino acids and energy in three Chinese corn distillers dried grains with solubles (DDGS), one rice DDGS, one American corn DDGS and one American high protein distillers dried grains (HP-DDG). In Exp. 1, the apparent ileal digestibility (AID) and standardized ileal digestibility (SID) of CP and amino acids in the six samples were determined using cannulated barrows (initial BW: $43.3 \pm 1.7 \mathrm{~kg}$ ). In Exp. 2, the digestible energy (DE) and metabolizable energy (ME) content of these six samples were determined using crossbred barrows (initial BW: $46.0 \pm 2.5 \mathrm{~kg}$ ). The results of the two experiments indicated that Chinese corn DDGS is generally similar to American DDGS in chemical composition, digestibility of amino acids, DE and ME. However, Chinese DDGS had a lower Lys concentration (0.50\% vs. 0.74\%) and SID Lys (52.3\% vs. 57.0\%, $\mathrm{p}<0.01$ ). The DE and ME values in Chinese corn DDGS were 3,427 and 3,306 kcal/kg, respectively. Rice DDGS had a similar DE and ME (3,363 and 3,228 kcal $/ \mathrm{kg}$ ) but higher Lys concentration (0.64\% vs. 0.50\%) to corn DDGS, while the SID of Lys was quite low (61.8\%, p $<0.01)$. HP-DDG had high value of SID of Lys, DE and ME (79.8\%, 3,899 and 3,746 kcal/kg). In conclusion, except for a lower Lys concentrations and availability, the chemical composition, digestibility of amino acids, DE and ME values in Chinese corn DDGS are similar to American corn DDGS. Additionally, the rice DDGS had lower Lys content and digestible Lys values than that in corn DDGS. Thirdly, HP-DDG has higher levels of digestible amino acids and energy than DDGS. (Key Words : Amino Acid Digestibility, Corn, Rice, Distillers Dried Grains with Solubles, Pigs)
\end{abstract}

\section{INTRODUCTION}

Distillers dried grain with solubles (DDGS) are a byproduct of the ethanol and alcoholic beverage industry. They contain considerable nutrients and are high in energy and protein content (Cromwell et al., 1993; Spiehs et al., 2002). With increased production in recent years, DDGS have been increasingly included in swine feed (Zhu et al., 2010). There has also been a rapid increase in use of DDGS in swine diets in China due to the price volatility of alternative ingredients and the recent development of an ethanol industry.

The nutrient content and digestibility of DDGS

\footnotetext{
* This project was financially supported by the National Key Technology R\&D Program in the 11th Five year Plan of China, 2006BAD12B01.

** Corresponding Author : L. M. Gong. Tel: +86-010-627337641103, Fax: +86-010-62733688, E-mail: glm0213@126.com

Received March 1, 2011; Accepted June 10, 2011
}

produced in the United States have been well characterized (Fastinger and Mahan, 2006; Stein et al., 2006; Pedersen et al., 2007). The composition and nutrient digestibility are affected by several factors such as the type of grain used to produce the DDGS, the quality of the solubles added back to the distillers dried grains and the level of heat damage (Pahm et al., 2008). However, there is very limited data on the nutrient digestibility of Chinese DDGS obtained from different grains or regions, imported DDGS, and HP-DDG from America. Therefore, the objective of this study was to determine the digestibility of amino acid in DDGS sourced from plants located in different Chinese provinces. The second objective was to compare the digestibility of different kinds of DDGS and HP-DDG from China and the U.S. The third objective was to determine the DE and ME in Chinese DDGS.

\section{MATERIALS AND METHODS}

All experimental procedures and animal care were 
approved by the China Agricultural University Animal Care and Use Committee.

\section{DDGS Samples}

Six DDGS samples were sourced from four provinces in China (Tables 1 and 2). The samples were obtained from Shandong province $(\mathrm{CH} 1)$, Jilin province $(\mathrm{CH} 2)$, Hebei province (CH3), and Heilongjiang province (CH4). Two American samples were imported from Minnesota by a local Chinese feed company (US and HP-DDG). All of these DDGS samples were obtained from ethanol plants and made from corn with the exception of the sample from
Heilongjiang (CH4), which was fermented from rice with bran. The HP-DDG contained 38\% CP.

\section{Determination of Amino Acid Digestibility (Exp. 1)}

In Exp. 1, seven cannulated barrows [Duroc $\times$ (Landrace $\times$ Yorkshire), initial BW: $43.3 \pm 1.7 \mathrm{~kg}$ ] were surgically fitted with a T-cannula in the distal ileum following the methods described by Stein et al. (1998). After the surgery, the barrows were allowed a two week recuperation period to recover from the surgery. The barrows were individually housed in $1.0 \times 1.8 \mathrm{~m}$ cages with a fully slatted floor in an environmentally controlled room $\left(20^{\circ} \mathrm{C}\right)$. Feed intake, rectal

Table 1. Analyzed nutrient composition of the sources of DDGS and HP-DDG, as-fed basis

\begin{tabular}{|c|c|c|c|c|c|c|c|}
\hline \multirow{3}{*}{$\begin{array}{l}\text { Items (\%) } \\
\text { Region } \\
\text { Grain }\end{array}$} & \multicolumn{6}{|c|}{ DDGS } & \multirow{3}{*}{$\begin{array}{c}\text { HP-DDG } \\
\mathrm{US2}^{4} \\
\text { Corn }\end{array}$} \\
\hline & \multirow{2}{*}{$\begin{array}{c}\mathrm{CH}^{1} \\
\text { Corn }\end{array}$} & \multirow{2}{*}{$\begin{array}{l}\mathrm{CH}^{1} \\
\text { Corn }\end{array}$} & \multirow{2}{*}{$\frac{\mathrm{CH}^{1}}{\text { Corn }}$} & \multirow{2}{*}{$\begin{array}{c}\text { Mean of } \\
\text { Chinese corn } \\
\text { DDGS }\end{array}$} & \multirow{2}{*}{$\begin{array}{l}\mathrm{CH}^{2}{ }^{2} \\
\text { Rice }\end{array}$} & \multirow{2}{*}{$\begin{array}{l}\mathrm{US1}^{3} \\
\text { Corn }\end{array}$} & \\
\hline & & & & & & & \\
\hline Dry matter (\%) & 89.28 & 89.08 & 89.27 & 89.21 & 90.79 & 88.46 & 91.17 \\
\hline Gross energy (kcal/kg) & 4,735 & 4,716 & 4,733 & 4,728 & 4,513 & 4,710 & 4,808 \\
\hline Crude protein (\%) & 23.60 & 28.49 & 24.99 & 25.69 & 28.55 & 25.78 & 39.92 \\
\hline Crude fat (\%) & 11.25 & 8.70 & 8.25 & 9.40 & 6.44 & 11.49 & 3.95 \\
\hline Crude fiber (\%) & 8.87 & 8.12 & 8.55 & 8.51 & 10.85 & 8.57 & 9.79 \\
\hline Neutral detergent fiber (\%) & 44.15 & 41.28 & 38.73 & 41.39 & 43.07 & 39.37 & 45.22 \\
\hline Acid detergent fiber (\%) & 16.45 & 16.88 & 13.22 & 15.52 & 17.39 & 11.63 & 12.87 \\
\hline Phosphorus (\%) & 0.49 & 0.22 & 0.34 & 0.35 & 0.41 & 0.28 & 0.04 \\
\hline \multicolumn{8}{|c|}{ Indispensable amino acids (\%) } \\
\hline Arginine & 0.86 & 1.12 & 0.96 & 0.98 & 1.47 & 1.20 & 1.50 \\
\hline Histidine & 1.06 & 1.00 & 0.90 & 0.99 & 1.01 & 0.88 & 1.28 \\
\hline Isoleucine & 0.76 & 0.99 & 0.82 & 0.86 & 0.93 & 0.84 & 1.43 \\
\hline Leucine & 2.74 & 3.64 & 3.14 & 3.17 & 2.94 & 2.82 & 5.44 \\
\hline Lysine & 0.41 & 0.60 & 0.48 & 0.50 & 0.64 & 0.74 & 0.99 \\
\hline Methionine & 0.50 & 0.65 & 0.56 & 0.57 & 0.61 & 0.50 & 0.90 \\
\hline Phenylalanine & 1.03 & 1.32 & 1.08 & 1.14 & 1.28 & 1.14 & 2.06 \\
\hline Threonine & 0.78 & 1.00 & 0.88 & 0.89 & 0.92 & 0.86 & 1.42 \\
\hline Tryptophan & 0.16 & 0.18 & 0.14 & 0.16 & 0.24 & 0.18 & 0.25 \\
\hline Valine & 1.03 & 1.28 & 1.06 & 1.12 & 1.39 & 1.15 & 1.88 \\
\hline \multicolumn{8}{|l|}{ Dispensable amino acids (\%) } \\
\hline Alanine & 1.58 & 2.06 & 1.78 & 1.81 & 1.84 & 1.70 & 3.07 \\
\hline Aspartic acid & 1.33 & 1.74 & 1.46 & 1.51 & 1.94 & 1.56 & 2.46 \\
\hline Cystine & 0.56 & 0.67 & 0.60 & 0.61 & 0.62 & 0.53 & 0.93 \\
\hline Glutamate & 3.20 & 4.50 & 3.64 & 3.78 & 4.08 & 3.24 & 6.75 \\
\hline Glycine & 0.80 & 0.98 & 0.84 & 0.87 & 1.10 & 0.94 & 1.32 \\
\hline Proline & 1.82 & 2.38 & 2.00 & 2.07 & 1.86 & 1.86 & 3.62 \\
\hline Serine & 1.05 & 1.38 & 1.15 & 1.19 & 1.34 & 1.18 & 2.00 \\
\hline Tyrosine & 0.82 & 1.10 & 1.01 & 0.98 & 1.08 & 0.94 & 1.65 \\
\hline Lysine:crude protein & 1.74 & 2.11 & 1.92 & 1.93 & 2.24 & 2.87 & 2.48 \\
\hline
\end{tabular}

${ }^{1}$ Chinese distillers dried grains with solubles produced from corn. CH1, CH2, CH3 were produced at Shandong, Jilin and Hebei province, respectively.

${ }^{2}$ Chinese distillers dried grains with solubles produced from rice, produced at Heilongjiang province.

${ }^{3}$ American (Minnesota) distillers dried grains with solubles produced from corn.

${ }^{4}$ American (Minnesota) high protein distillers dried grains. 
Table 2. Analyzed micro mineral composition ( $\mathrm{mg} / \mathrm{kg}$ ) of the sources of DDGS and HP-DDG, as-fed basis

\begin{tabular}{lccccccrcr}
\hline Region & Grains & Copper & Iron & Zinc & Manganese & Potassium & Sodium & Calcium & Magnesium \\
\hline $\mathrm{CH} 1^{1}$ & Corn & 6.00 & 432.00 & 44.48 & 21.99 & 10,300 & 4,060 & $1,360.0$ & 3,200 \\
$\mathrm{CH}{ }^{1}$ & Corn & 4.95 & 115.00 & 37.07 & 15.32 & 12,100 & 2,020 & 57.8 & 2,760 \\
$\mathrm{CH}^{1}$ & Corn & 4.92 & 248.00 & 40.86 & 36.44 & 9,060 & 2,100 & 827.0 & 2,680 \\
$\mathrm{CH} 4{ }^{2}$ & Rice & 6.92 & 350.00 & 53.94 & 76.70 & 10,500 & 1,860 & 757.0 & 3,660 \\
$\mathrm{US}^{3}$ & Corn & 4.94 & 65.16 & 46.89 & 12.34 & 10,800 & 2,450 & 48.4 & 3,060 \\
$\mathrm{US}^{4}$ & Corn & 2.85 & 43.29 & 25.96 & 7.60 & 3,040 & 178 & 56.7 & 490 \\
\hline
\end{tabular}

${ }^{1}$ Chinese distillers dried grains with solubles produced from corn. CH1, CH2, CH3 were produced at Shandong, Jilin and Hebei province, respectively.

${ }^{2}$ Chinese distillers dried grains with solubles produced from rice, produced at Heilongjiang province.

${ }^{3}$ American (Minnesota) distillers dried grains with solubles produced from corn.

${ }^{4}$ American (Minnesota) high protein distillers dried grains.

temperature and integrity of the cannula were checked daily. The site where the cannula was exteriorized was washed with water every day. Zinc cream was applied daily during the experiment.

Six semi-purified diets based on DDGS or HP-DDG were formulated (Tables 3 and 4). The concentration of CP of the six treatments was maintained at the same level. In addition, a $\mathrm{N}$-free diet was formulated to determine the basal endogenous nitrogen lost. $0.30 \%$ Chromic oxide was used as indigestible marker in the experimental diets (Stein et al., 2006). A $7 \times 7$ Latin-square design was used with seven diets and seven collection periods with each period lasting $7 \mathrm{~d}$. The initial $5 \mathrm{~d}$ of each $7 \mathrm{~d}$ period were used to adapt the pigs to their experimental diets. On d 6 and 7 of every period, ileal digesta were collected with a rubber bag from 08:30 to 18:30. Bags were changed every $30 \mathrm{~min}$ or when they were full. After collection, all the samples were immediately stored at $-20^{\circ} \mathrm{C}$ and were lyophilized before chemical analyses. The body weight of each barrow was measured at the beginning of every period. The pigs were fed at $9 \%$ of their metabolic body weight $\left(\mathrm{BW}^{0.75}\right)$. Daily feed allowances were divided into 2 equal meals and fed at 08:00 and 18:00. Water was available ad libitum.

\section{Determination of DE and ME}

In Exp. 2, seven crossbred barrows [(Yorkshirex Landrace) $\times$ Duroc, initial BW: $46.0 \pm 2.5 \mathrm{~kg}$ ] were used to measure the DE and ME content in the six DDGS samples. A basal diet based on corn (96.66\%), limestone, salt, vitamins and minerals was formulated. The remaining six diets were formulated by mixing $50 \%$ corn with $48.3 \%$ as well as $1.7 \%$ of limestone, salt, vitamins and minerals (Tables 5 and 6). All the barrows were allotted to a $7 \times 7$ Latin-square design with seven diets and seven collection periods each with an experimental period lasting $7 \mathrm{~d}$. Pigs were housed in the same conditions as Exp. 1.

Body weight of each barrow was measured at the beginning of every period. The pigs were fed at $9 \%$ of their

Table 3. Ingredient composition of the diets of Exp.1, as-fed basis

\begin{tabular}{lccc}
\hline Ingredient (\% of diet) & Nitrogen-free diet & DDGS diet & HP-DDG diet \\
\hline DDGS & - & 60.0 & - \\
HP-DDG & - & - & 50.0 \\
Cornstarch & 65.8 & 10.4 & 10.4 \\
Sucrose & 25.0 & 25.0 & 35.0 \\
Soybean oil & 2.0 & 2.0 & 2.0 \\
Solka floc $^{1}$ & 3.0 & - & - \\
Dicalcium phosphate $^{\text {Limestone }}$ & 2.5 & - & - \\
Salt $^{\text {Chromic oxide }}{ }^{1}$ & - & 1.4 & 1.4 \\
Vitamin and micromineral $^{2}$ premix & 0.5 & 0.4 & 0.4 \\
Potassium carbonate $^{\text {Magnesium } \text { oxide }}$ & 0.3 & 0.3 & 0.3 \\
\hline
\end{tabular}

${ }^{1}$ Made by Chemical Reagents Company, Beijing, China.

${ }^{2}$ Provided the following quantities of vitamins and microminerals per kg of complete diet: Mn, $50 \mathrm{mg}(\mathrm{MnO}) ; \mathrm{Fe}, 125 \mathrm{mg}\left(\mathrm{FeSO}_{4} \cdot \mathrm{H}_{2} \mathrm{O}\right) ; \mathrm{Zn}, 125 \mathrm{mg}$ (ZnO); $\mathrm{Cu}, 150 \mathrm{mg}\left(\mathrm{CuSO}_{4} \cdot 5 \mathrm{H} 2 \mathrm{O}\right) ; \mathrm{I}, 50 \mathrm{mg}\left(\mathrm{CaI}_{2}\right)$; Se, $0.48 \mathrm{mg}\left(\mathrm{Na}_{2} \mathrm{SeO}_{3}\right)$, retinyl acetate, 4,500 IU; cholecalciferol, 1,350 IU; DL- $\alpha$-tocopheryl

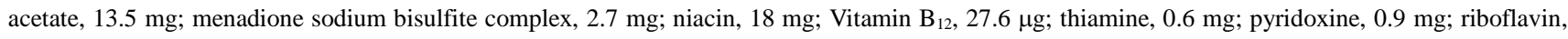
$1.8 \mathrm{mg}$; D-Ca-pantothenate, $10.8 \mathrm{mg}$; nicotinic acid, $30.3 \mathrm{mg}$; choline chloride, $210 \mathrm{mg}$. 
Table 4. Analyzed nutrient composition of diets used in Exp.1, as-fed basis

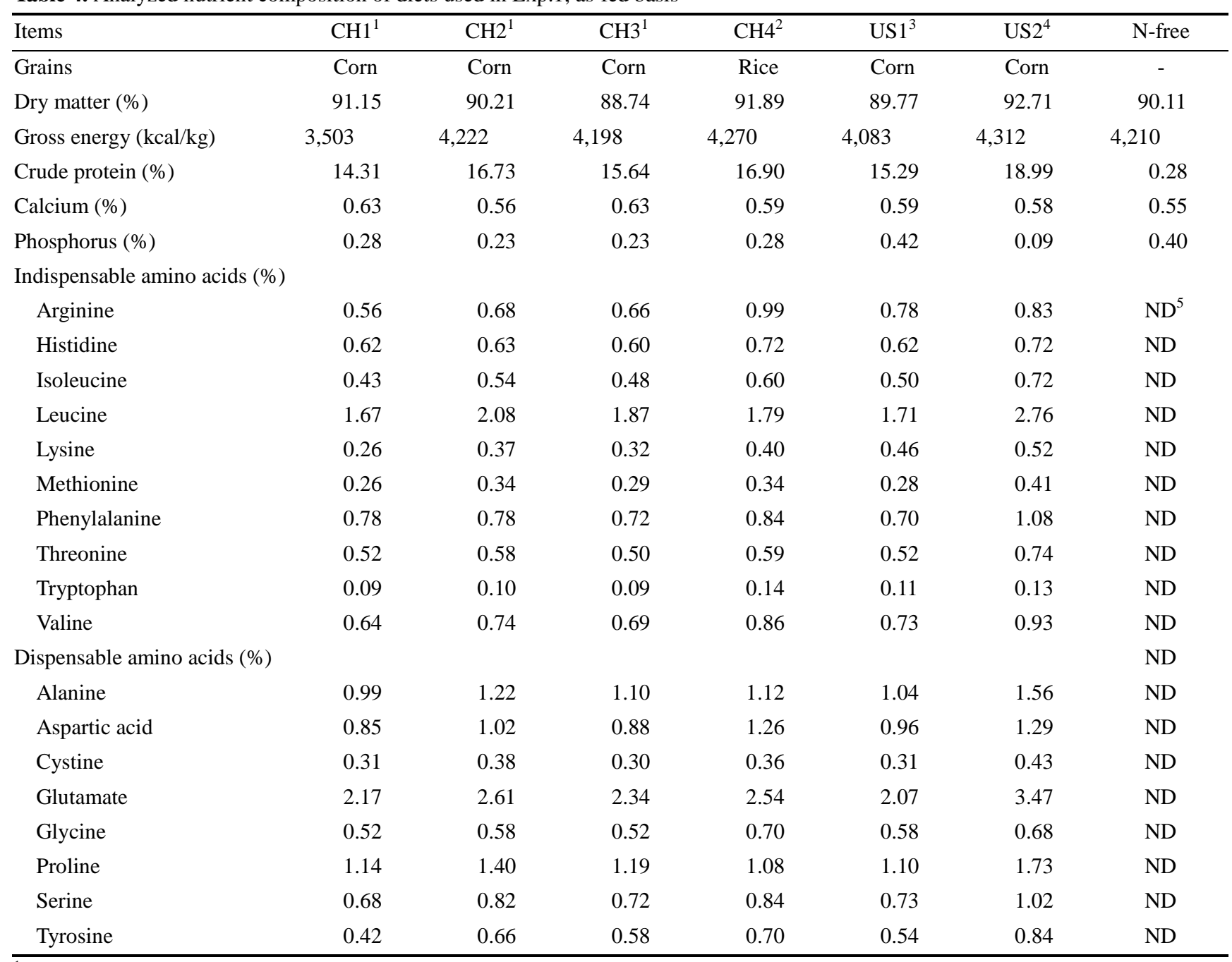

${ }^{1}$ Chinese distillers dried grains with solubles produced from corn. CH1, CH2, CH3 were produced at Shandong, Jilin and Hebei province, respectively.

${ }^{2}$ Chinese distillers dried grains with solubles produced from rice, produced at Heilongjiang province.

${ }^{3}$ American (Minnesota) distillers dried grains with solubles produced from corn.

${ }^{4}$ American (Minnesota) high protein distillers dried grains. ${ }^{5}$ Not determined.

Table 5. Ingredient composition of diets used in Exp.2, as-fed basis

\begin{tabular}{lccc}
\hline Ingredient (\% of diet) & Corn & Corn- DDGS & Corn- HP-DDG \\
\hline DDGS & - & 50.0 & - \\
HP-DDG & & - & 50.0 \\
Corn & 96.7 & 48.3 & 48.3 \\
Limestone & 2.2 & 1.1 & 1.1 \\
Salt & 0.6 & 0.3 & 0.3 \\
Vitamin-mineral premix ${ }^{1}$ & 0.5 & 0.3 & 0.3 \\
\hline
\end{tabular}

\footnotetext{
${ }^{1}$ Provided the following quantities of vitamins and microminerals per kg of complete diet: Mn, $50 \mathrm{mg}(\mathrm{MnO}) ; \mathrm{Fe}, 125 \mathrm{mg}\left(\mathrm{FeSO} \cdot \mathrm{H}_{2} \mathrm{O}\right) ; \mathrm{Zn}, 125 \mathrm{mg}$ (ZnO); $\mathrm{Cu}, 150 \mathrm{mg}\left(\mathrm{CuSO}_{4} \cdot 5 \mathrm{H} 2 \mathrm{O}\right)$; I, $50 \mathrm{mg}\left(\mathrm{CaI}_{2}\right)$; Se, $0.48 \mathrm{mg}\left(\mathrm{Na}_{2} \mathrm{SeO}_{3}\right)$, retinyl acetate, 4,500 IU; cholecalciferol, 1,350 IU; DL- $\alpha$-tocopheryl acetate, $13.5 \mathrm{mg}$; menadione sodium bisulfite complex, $2.7 \mathrm{mg}$; niacin, $18 \mathrm{mg}$; Vitamin $\mathrm{B}_{12}$, 27.6 $\mu \mathrm{g}$; thiamine, $0.6 \mathrm{mg}$; pyridoxine, $0.9 \mathrm{mg}$; riboflavin, $1.8 \mathrm{mg}$; D-Ca-pantothenate, $10.8 \mathrm{mg}$; nicotinic acid, $30.3 \mathrm{mg}$; choline chloride, $210 \mathrm{mg}$.
} 
Table 6. Analyzed nutrient composition of diets used in Exp.2, as-fed basis

\begin{tabular}{|c|c|c|c|c|c|c|c|}
\hline \multirow{2}{*}{ Items } & \multirow[b]{2}{*}{ Corn } & \multicolumn{5}{|c|}{ Corn-DDGS diets using DDGS source } & \multirow{2}{*}{$\frac{\text { Corn - HP-DDG diet }}{\mathrm{US}^{4}}$} \\
\hline & & $\mathrm{CH} 1^{1}$ & $\mathrm{CH} 2^{1}$ & $\mathrm{CH}^{1}$ & $\mathrm{CH} 4^{2}$ & $\mathrm{US}^{3}$ & \\
\hline Grains & - & Corn & Corn & Corn & Rice & Corn & Corn \\
\hline Dry matter (\%) & 92.44 & 90.88 & 89.67 & 90.79 & 90.21 & 93.23 & 91.51 \\
\hline Gross energy (kcal/kg) & 3,579 & 4,103 & 4,065 & 4,095 & 4,003 & 4,141 & 4,182 \\
\hline Crude protein (\%) & 7.10 & 15.44 & 16.97 & 15.54 & 15.88 & 17.05 & 22.91 \\
\hline Calcium (\%) & 0.44 & 0.42 & 0.47 & 0.48 & 0.43 & 0.46 & 0.87 \\
\hline Phosphorus (\%) & 0.37 & 0.36 & 0.31 & 0.43 & 0.38 & 0.15 & 0.18 \\
\hline \multicolumn{8}{|c|}{ Indispensable amino acids (\%) } \\
\hline Arginine & 0.58 & 0.74 & 0.70 & 0.96 & 0.86 & 1.00 & 0.42 \\
\hline Histidine & 0.70 & 0.70 & 0.64 & 0.72 & 0.65 & 0.86 & 0.33 \\
\hline Isoleucine & 0.46 & 0.58 & 0.54 & 0.64 & 0.58 & 0.85 & 0.23 \\
\hline Leucine & 1.64 & 2.20 & 2.04 & 1.95 & 1.94 & 3.22 & 0.86 \\
\hline Lysine & 0.31 & 0.42 & 0.34 & 0.46 & 0.53 & 0.64 & 0.23 \\
\hline Methionine & 0.29 & 0.35 & 0.30 & 0.34 & 0.31 & 0.46 & 0.14 \\
\hline Phenylalanine & 0.65 & 0.84 & 0.79 & 0.89 & 0.80 & 1.26 & 0.35 \\
\hline Threonine & 0.52 & 0.56 & 0.54 & 0.60 & 0.62 & 0.84 & 0.26 \\
\hline Tryptophan & 0.10 & 0.12 & 0.10 & 0.16 & 0.13 & 0.17 & 0.06 \\
\hline Valine & 0.67 & 0.80 & 0.74 & 0.90 & 0.80 & 1.14 & 0.38 \\
\hline \multicolumn{8}{|c|}{ Dispensable amino acids (\%) } \\
\hline Alanine & 0.98 & 1.26 & 1.17 & 1.18 & 1.18 & 1.84 & 0.54 \\
\hline Aspartic acid & 0.89 & 1.06 & 0.97 & 1.27 & 1.12 & 1.52 & 0.54 \\
\hline Cystine & 0.31 & 0.37 & 0.33 & 0.34 & 0.32 & 0.49 & 0.17 \\
\hline Glutamate & 2.14 & 2.77 & 2.61 & 2.74 & 2.52 & 4.12 & 1.28 \\
\hline Glycine & 0.52 & 0.60 & 0.56 & 0.70 & 0.67 & 0.81 & 0.29 \\
\hline Proline & 1.10 & 1.42 & 1.32 & 1.17 & 1.28 & 2.02 & 0.64 \\
\hline Serine & 0.66 & 0.82 & 0.77 & 0.86 & 0.81 & 1.20 & 0.38 \\
\hline Tyrosine & 0.48 & 0.60 & 0.57 & 0.66 & 0.62 & 0.95 & 0.27 \\
\hline
\end{tabular}

${ }^{1}$ Chinese distillers dried grains with solubles produced from corn. CH1, CH2, CH3 were produced at Shandong, Jilin and Hebei province, respectively.

${ }^{2}$ Chinese distillers dried grains with solubles produced from rice, produced at Heilongjiang province.

${ }^{3}$ American (Minnesota) distillers dried grains with solubles produced from corn.

${ }^{4}$ American (Minnesota) high protein distillers dried grains.

metabolic body weight $\left(\mathrm{BW}^{0.75}\right)$. Daily feed allowances were divided into 2 equal meals and fed at 08:00 and 18:00. Water was available ad libitum.

Each period consisted of a $4 \mathrm{~d}$ adaptation period and a 3 $\mathrm{d}$ collection period. All feces and urine of the last $3 \mathrm{~d}$ in every period were collected. Collection began at 08:30 on $\mathrm{d}$ 5 and ended at 08:30 on $\mathrm{d} 1$ of the next period. The feces were gathered just after excretion or at $08: 30$ and 18:30 of every collection day and stored at $-20^{\circ} \mathrm{C}$. Urine buckets were placed under the floor of the metabolism cages. The buckets were emptied twice a day, and $50 \mathrm{ml}$ of $6 \mathrm{~N}$ sulfuric acid was added to the buckets when they were emptied. After being weighed, $20 \%$ of each urine sample was stored at $-20^{\circ} \mathrm{C}$. After the experiment, the feces were lyophilized, then ground before chemical analyses. Feces and urine samples were mixed respectively within animal and diet, and a subsample was collected for chemical analysis.

\section{Sample preparation and chemical analysis}

Analyses of all samples were conducted in duplicate. The analyses were repeated if the results of the duplicates differed by more than 5\%. The DDGS, HP-DDG, corn, diets, and feces samples were analyzed for dry matter (procedure 930.15, AOAC). All the feeds, DDGS, HP-DDG and digesta samples, including feces and urine were analyzed for gross energy, (via bomb calorimetry, Parr Instruments, Moline, IL). Kjeldahl N were analyzed with Kjeltec ${ }^{\mathrm{TM}} 2100$ semi-automatic analyzer (Thiex et al., 2002). The amino acid content of DDGS, HP-DDG, feeds and digesta samples were determined by high performance liquid chromatography (Hitachi L-8800 Amino Acid Analyzer, Tokyo, Japan). All samples were hydrolyzed for $24 \mathrm{~h}$ at 
$110^{\circ} \mathrm{C}$ with $6 \mathrm{~N} \mathrm{HCl}$ before analysis (procedure 4.1.11, alt. 3, AOAC, 1998). Sulfur-containing amino acids were analyzed after cold formic acid oxidation for $16 \mathrm{~h}$ before acid hydrolysis (procedure 4.1.11, alt.1, AOAC, 1998). Tryptophan was determined after alkaline hydrolysis (4 N $\mathrm{NaOH}$ ) for $22 \mathrm{~h}$ at $110^{\circ} \mathrm{C}$ (procedure 988.15, AOAC, 1995). All samples of diets and ileal digesta were analyzed for $\mathrm{Cr}$ (procedure 9.2.39; AOAC, 2000) after nitric acid-perchloric acid wet ash sample preparation.

\section{Calculations and statistical analysis}

The apparent ileal digestibilities (AID, \%) of each DDGS were calculated using the Eq. (1) (Stein et al., 2007):

$$
\mathrm{AID}=\left[1-\left(\mathrm{AA}_{\mathrm{d}} / \mathrm{AA}_{\mathrm{f}}\right) \times\left(\mathrm{Cr}_{\mathrm{f}} / \mathrm{Cr}_{\mathrm{d}}\right)\right] \times 100 \%
$$

in which $\mathrm{AA}_{d}$ was the concentration of that amino acid in the ileal digesta $(\mathrm{g} / \mathrm{kg}$ of $\mathrm{DM}), \mathrm{AA}_{\mathrm{f}}$ was the concentration of that amino acid in the diet $(\mathrm{g} / \mathrm{kg}$ of $\mathrm{DM}), \mathrm{Cr}_{\mathrm{f}}$ was the chromium concentration in the diet $(\mathrm{g} / \mathrm{kg}$ of $\mathrm{DM})$, and $\mathrm{Cr}_{\mathrm{d}}$ was the chromium concentration in the ileal digesta $(\mathrm{g} / \mathrm{kg}$ of $\mathrm{DM})$. The AID for CP was also calculated using this equation.

Basal ileal endogenous losses (basal $\mathrm{IAA}_{\text {end, }} \mathrm{g} / \mathrm{kg}$ of $\mathrm{DMI})$ were calculated based on the digesta obtained from the N-free diet, using Eq. (2) (Stein et al., 2007):

$$
\mathrm{IAA}_{\text {end }}=\left[\mathrm{AA}_{\mathrm{d}} \times\left(\mathrm{Cr}_{\mathrm{f}} / \mathrm{Cr}_{\mathrm{d}}\right)\right]
$$

The endogenous loss of $\mathrm{CP}$ was determined using the same equation.

Standardized ileal digestibilities (SID, \%) of CP and amino acids of each DDGS were calculated using Eq. (3) (Stein et al., 2007):

$$
\operatorname{SID}=\left[\mathrm{AID}+\left(\mathrm{IAA}_{\text {end }} / \mathrm{AA}_{\mathrm{f}}\right)\right]
$$

The SID of CP was determined using the same equation.

After chemical analysis, the energy lost in feces and urine was calculated for each diet, and the DE and ME in each of the 7 diets were calculated. By subtracting the DE and $\mathrm{ME}$ contributed by the corn diet to the experimental diets, the DE and ME contributed by each source of DDGS were calculated by their difference (Adeola, 2001). Energy of urine was determined for the calculation of ME.

\section{Statistical analysis}

Data were statistically analyzed using the MIXED procedure of SAS (SAS 8.2 Inst. Inc., Cary, NC). Each pig was an experimental unit. The 6 sources of DDGS were compared using an ANOVA with DDGS source, pig, and period as the main effects. In both experiments, the CONTRAST option of SAS was used to compare values from DDGS sourced from different regions and fermented from different grains. An alpha level of 0.05 was used to assess significance among means.

\section{RESULTS}

\section{Chemical composition of samples}

Analysis of the chemical composition of DDGS (Tables $1,2)$ showed that DDGS produced from rice (CH4) had the lowest crude fat and gross energy level (6.44\% and 4,513 $\mathrm{kcal} / \mathrm{kg}$ ) among all the samples, while the concentration of crude fiber was the highest (10.85\%). Compared with the American corn DDGS sample (US1), Chinese corn DDGS had a similar nutrient level except for higher levels of ADF, $\mathrm{P}$ and micro minerals and a lower level of Lys (0.50\% vs. $0.74 \%$ ). Due to the low level of Lys, the Lys to CP ratio of Chinese corn DDGS is lower than that of American DDGS (1.93\% vs. $2.87 \%)$.

\section{Apparent ileal amino acids digestibility}

The results of the AID value of amino acids and CP in all DDGS samples are shown in Table 7. There was significant difference in AID values of Ile, Leu, Lys, Met and Phe between the three Chinese corn DDGS samples. The AID of Lys was greater in DDGS from Hebei (CH3) than in DDGS from Jilin (CH2) and Shandong $(\mathrm{CH} 1)$ $(p<0.01)$. The mean of AID of Lys was $45.1 \%$ and ranged from $41.9 \%$ to $49.3 \%$. The AID of amino acids in Chinese corn DDGS was similar to the DDGS from the US (US1), except for higher values of Pro and Phe and a lower value of Lys $(p<0.05)$. The AID of all the amino acids of rice DDGS (CH4) was lower than the AID in the four corn DDGS samples $(p<0.01)$, except for Arg. The AID of Lys in rice DDGS was $35.7 \%$. Except the AID of Val, all the AID of essential amino acids of HP-DDG (US2) were significantly different from corn DDGS $(\mathrm{p}<0.05)$. The AID of Lys in HP-DDG was 51.8\% Which was greater than corn DDGS $(\mathrm{p}<0.05)$.

\section{Standardized ileal amino acids digestibility}

The results of the SID value of amino acids and CP in all the DDGS samples are shown in Table 8. The SID had significant differences in the values of Ile, Leu, Lys, Met, Phe among the three Chinese corn DDGS samples. The SID of Lys is greater in DDGS from Hebei (CH3) than that of DDGS from Jilin $(\mathrm{CH} 2)$ and Shandong $(\mathrm{CH} 1)(\mathrm{p}<0.01)$, thus it was in the same situation as the AID of Lys. The mean of SID of Lys was $52.3 \%$ and ranged from $48.8 \%$ to $57.0 \%$. The SID of amino acids in Chinese corn DDGS was similar to the DDGS from the US (US1) except for higher values of Pro and Phe and a lower value of Lys $(\mathrm{p}<0.05)$, which also applied for the comparison of AID. The rice DDGS (CH4) had lower SID of all the amino acids than the 
Table 7. Apparent ileal crude protein and amino acid digestibility (\%) of samples of DDGS and HP-DDG (Exp. 1)

\begin{tabular}{|c|c|c|c|c|c|c|c|c|c|c|c|c|}
\hline \multirow{3}{*}{$\begin{array}{l}\text { Items } \\
\text { Region } \\
\text { Grains }\end{array}$} & \multicolumn{6}{|c|}{ DDGS } & \multirow{3}{*}{$\begin{array}{c}\frac{\text { HP-DDG }}{\mathrm{US}^{4}} \\
\text { Corn }\end{array}$} & \multirow{3}{*}{ SEM } & \multirow{3}{*}{$\mathrm{p}$ value } & \multicolumn{3}{|c|}{$\mathrm{p}$ values for contrast } \\
\hline & \multirow{2}{*}{$\begin{array}{l}\mathrm{CH}^{1}{ }^{1} \\
\text { Corn }\end{array}$} & $\mathrm{CH} 2^{1}$ & $\mathrm{CH}^{1}{ }^{1}$ & \multirow{2}{*}{$\begin{array}{c}\text { Mean of } \\
\text { Chinese } \\
\text { corn } \\
\text { DDGS }\end{array}$} & \multirow{2}{*}{$\begin{array}{c}\mathrm{CH}^{2} \\
\text { Rice }\end{array}$} & \multirow{2}{*}{$\frac{\mathrm{US1}^{3}}{\text { Corn }}$} & & & & \multirow{2}{*}{$\begin{array}{l}\mathrm{CH} \\
\mathrm{vs} . \\
\mathrm{US}^{5}\end{array}$} & \multirow{2}{*}{$\begin{array}{c}\text { Corn } \\
\text { vs. } \\
\text { rice }^{6}\end{array}$} & \multirow{2}{*}{$\begin{array}{l}\text { D } \\
\text { vs. } \\
\mathrm{H}^{7}\end{array}$} \\
\hline & & Corn & Corn & & & & & & & & & \\
\hline \multicolumn{13}{|c|}{ Indispensable amino acids } \\
\hline Arginine & 55.7 & 61.1 & 73.4 & 63.4 & 67.5 & 73.9 & 77.7 & 3.8 & 0.04 & 0.16 & 0.83 & 0.09 \\
\hline Histidine & 71.8 & 70.7 & 73.9 & 72.1 & 58.6 & 71.2 & 75.1 & 2.7 & $<0.01$ & 0.39 & $<0.01$ & 0.00 \\
\hline Isoleucine & 41.7 & 39.7 & 55.2 & 45.5 & 22.0 & 48.9 & 61.6 & 6.3 & $<0.01$ & 0.39 & $<0.01$ & $<0.01$ \\
\hline Leucine & 76.3 & 76.6 & 77.6 & 76.8 & 71.0 & 76.3 & 78.8 & 1.2 & $<0.01$ & 0.19 & $<0.01$ & $<0.01$ \\
\hline Lysine & 41.9 & 43.9 & 49.3 & 45.1 & 35.7 & 49.6 & 51.8 & 2.7 & $<0.01$ & 0.05 & $<0.01$ & 0.01 \\
\hline Methionine & 55.2 & 54.9 & 62.5 & 57.5 & 35.4 & 54.4 & 66.5 & 4.9 & $<0.01$ & 0.21 & $<0.01$ & $<0.01$ \\
\hline Phenylalanine & 71.6 & 68.7 & 72.6 & 71.0 & 61.9 & 66.6 & 74.4 & 2.1 & $<0.01$ & $<0.01$ & $<0.01$ & $<0.01$ \\
\hline Threonine & 62.0 & 59.0 & 64.5 & 61.8 & 47.4 & 59.4 & 69.1 & 3.3 & $<0.01$ & 0.26 & $<0.01$ & $<0.01$ \\
\hline Tryptophan & 54.1 & 47.6 & 51.4 & 51.0 & 40.5 & 49.7 & 60.5 & 3.0 & 0.04 & 0.79 & 0.04 & 0.03 \\
\hline Valine & 73.1 & 73.6 & 77.8 & 74.8 & 61.3 & 73.8 & 74.2 & 2.6 & 0.04 & 0.67 & 0.00 & 0.86 \\
\hline \multicolumn{13}{|l|}{ Dispensable amino acids } \\
\hline Alanine & 73.8 & 73.8 & 76.5 & 74.7 & 66.4 & 74.2 & 77.0 & 1.7 & $<0.01$ & 0.71 & $<0.01$ & 0.06 \\
\hline Aspartic acid & 62.8 & 60.8 & 66.7 & 63.4 & 48.8 & 63.4 & 71.0 & 3.4 & $<0.01$ & 0.98 & $<0.01$ & $<0.01$ \\
\hline Cystine & 48.6 & 47.5 & 54.3 & 50.1 & 18.1 & 46.3 & 61.1 & 6.7 & $<0.01$ & 0.20 & $<0.01$ & $<0.01$ \\
\hline Glutamate & 67.9 & 66.9 & 72.1 & 69.0 & 54.9 & 68.3 & 73.6 & 3.0 & $<0.01$ & 0.62 & $<0.01$ & $<0.01$ \\
\hline Glycine & 57.8 & 55.8 & 62.3 & 58.7 & 45.0 & 60.2 & 65.0 & 3.2 & $<0.01$ & 0.51 & $<0.01$ & 0.01 \\
\hline Proline & 69.5 & 69.7 & 72.5 & 70.6 & 54.2 & 67.5 & 74.4 & 3.3 & $<0.01$ & 0.02 & $<0.01$ & $<0.01$ \\
\hline Serine & 66.7 & 66.3 & 70.3 & 67.8 & 54.9 & 66.5 & 73.3 & 2.8 & $<0.01$ & 0.34 & $<0.01$ & $<0.01$ \\
\hline Tyrosine & 60.0 & 64.5 & 68.7 & 64.4 & 51.6 & 64.1 & 72.5 & 3.3 & $<0.01$ & 0.87 & $<0.01$ & $<0.01$ \\
\hline Total indispensable & 60.3 & 59.6 & 65.8 & 61.9 & 50.1 & 62.4 & 69.0 & 2.6 & $<0.01$ & 0.83 & $<0.01$ & $<0.01$ \\
\hline Total dispensable & 63.4 & 63.2 & 67.9 & 64.8 & 49.2 & 63.8 & 71.0 & 3.0 & $<0.01$ & 0.54 & $<0.01$ & $<0.01$ \\
\hline Total amino acids & 61.7 & 61.2 & 66.8 & 63.2 & 49.7 & 63.0 & 69.9 & 2.8 & $<0.01$ & 0.91 & $<0.01$ & $<0.01$ \\
\hline Crude protein & 59.1 & 58.6 & 64.1 & 60.6 & 46.9 & 60.3 & 67.2 & 2.8 & $<0.01$ & 0.78 & $<0.01$ & $<0.01$ \\
\hline
\end{tabular}

${ }^{1}$ Chinese distillers dried grains with solubles produced from corn. CH1, CH2, CH3 were produced at Shandong, Jilin and Hebei province, respectively.

${ }^{2}$ Chinese distillers dried grains with solubles produced from rice, produced at Heilongjiang province.

${ }^{3}$ American (Minnesota) distillers dried grains with solubles produced from corn.

${ }^{4}$ American (Minnesota) high protein distillers dried grains.

${ }^{5}$ Chinese corn DDGS vs. US corn DDGS. ${ }^{6}$ Corn DDGS vs. rice. ${ }^{7}$ Corn DDGS vs. HP Corn DDGS.

SID in the four corn DDGS samples $(\mathrm{p}<0.05)$, but no difference in Arg was observed. The SID of Lys in rice DDGS was $41.8 \%$. All the SID of essential amino acids of HP-DDG (US2) were significantly different from corn DDGS, except for the SID of Val. The SID of Lys in HPDDG was $59.8 \%$ and greater than that of corn DDGS $(\mathrm{p}<$ $0.05)$.

\section{Digestible and metabolizable energy}

DE and ME of DDGS samples are shown in Table 9. Among the three Chinese corn DDGS samples, DDGS from Jilin province $(\mathrm{CH} 2)$ contained greater $\mathrm{DE}(\mathrm{p}<0.05)$ and $\mathrm{ME}(\mathrm{p}<0.01)$ than DDGS from Shandong province $(\mathrm{CH} 1)$ and Hebei province (CH3). The means of DE and ME in Chinese corn DDGS were 3,427 and 3,306 kcal/kg, respectively. There was no significant difference between Chinese corn DDGS samples and the American sample in
DE and ME. The DE and ME of rice DDGS was 3,158 and $3,047 \mathrm{kcal} / \mathrm{kg}$, respectively. The difference in SID values between corn DDGS and rice DDGS was not observed, but HP-DDG contained greater DE and ME than corn DDGS $(\mathrm{p}<0.01)$.

\section{DISCUSSION}

\section{Nutrient composition of different kinds of DDGS and HP-DDG}

Most of the values of nutrient composition, such as the AID and SID of CP and amino acids and the DE and ME, of the 4 corn DDGS were in the range of previously reported values (Spiehs et al., 2002; Fastinger and Mahan, 2006; Stein et al., 2006). The values of HP-DDG were similar to the results that were reported by Widmer et al. (2007) and Kim et al. (2009). However, there is no data reporting the 
Table 8. Standardized ileal crude protein and amino acid digestibility (\%) of samples of DDGS and HP-DDG (Exp.1)

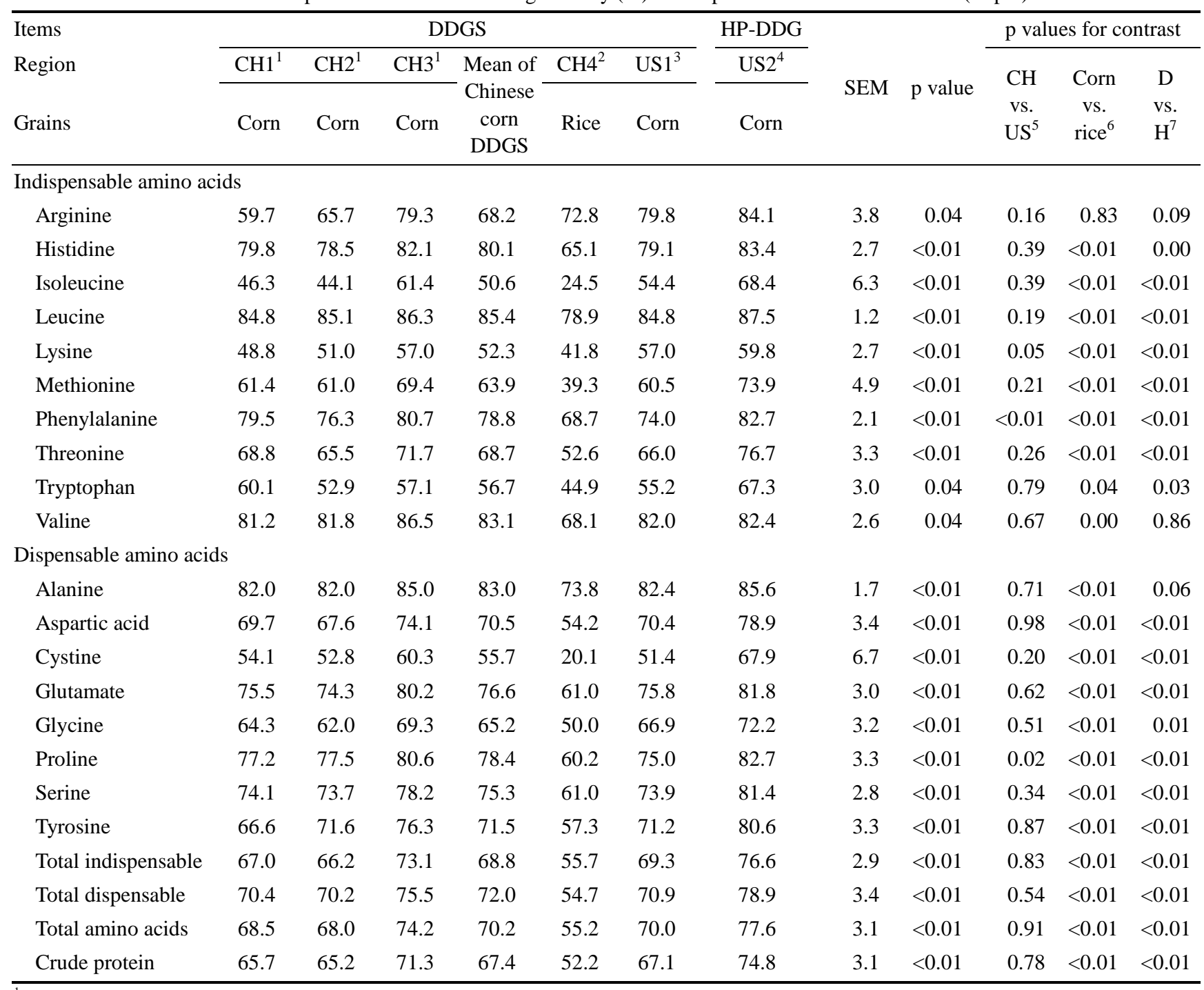

${ }^{1}$ Chinese distillers dried grains with solubles produced from corn. CH1, CH2, CH3 were produced at Shandong, Jilin and Hebei province, respectively.

${ }^{2}$ Chinese distillers dried grains with solubles produced from rice, produced at Heilongjiang province.

${ }^{3}$ American (Minnesota) distillers dried grains with solubles produced from corn.

${ }^{4}$ American (Minnesota) high protein distillers dried grains.

${ }^{5}$ Chinese corn DDGS vs. US corn DDGS. ${ }^{6}$ Corn DDGS vs. rice. ${ }^{7}$ Corn DDGS vs. HP Corn DDGS.

Table 9. Energy (kcal/kg) values for corn, DDGS and HP-DDGS (Exp. 2)

\begin{tabular}{|c|c|c|c|c|c|c|c|c|c|c|c|c|}
\hline \multirow{3}{*}{$\begin{array}{l}\text { Items } \\
\text { Region } \\
\text { Grains }\end{array}$} & \multirow{3}{*}{ Corn } & \multicolumn{6}{|c|}{ DDGS } & \multirow{3}{*}{$\frac{\frac{\mathrm{HP}-\mathrm{DDG}}{\mathrm{US2}^{4}}}{\mathrm{Corn}}$} & \multirow[b]{3}{*}{ SEM } & \multirow[b]{3}{*}{$\mathrm{p}$ value } & \multicolumn{2}{|c|}{$\mathrm{p}$ values for contrast } \\
\hline & & $\mathrm{CH}^{1}{ }^{1}$ & $\mathrm{CH}{ }^{1}$ & $\mathrm{CH}^{1}{ }^{1}$ & Mean of & $\mathrm{CH}_{4}{ }^{2}$ & $\mathrm{US}^{3}{ }^{3}$ & & & & $\mathrm{CH}$ & Corn \\
\hline & & Corn & Corn & Corn & $\begin{array}{c}\text { Chinese } \\
\text { corn } \\
\text { DDGS }\end{array}$ & Rice & Corn & & & & $\begin{array}{l}\text { vs. } \\
\text { US }^{5}\end{array}$ & $\begin{array}{c}\text { vs. } \\
\text { Rice }^{6}\end{array}$ \\
\hline Gross energy & 3,990 & 4,735 & 4,716 & 4,733 & 4,728 & 4,513 & 4,710 & 4,808 & - & - & - & - \\
\hline Digestible energy & 3,483 & 3,442 & 3,682 & 3,158 & 3,427 & 3,363 & 3,659 & 3,899 & 108.0 & $<0.01$ & 0.15 & 0.40 \\
\hline Metabolizable energy & 3,351 & 3,320 & 3,549 & 3,047 & 3,306 & 3,228 & 3,525 & 3,746 & 103.0 & $<0.01$ & 0.16 & 0.35 \\
\hline
\end{tabular}


nutrient composition and digestibility of rice DDGS. Compared with corn DDGS, the rice DDGS sample contained less Lys and crude fat, but higher crude fiber and ADF which may be due to the different grain compositions. Rice contained less crude fat than corn $(1.0 \%$ vs. $3.9 \%$, NRC, 1998), but a higher level of NDF and ADF (12.2\% vs. 9.6\%, 3.1\% vs. 2.8\%, respectively, NRC, 1998). Chinese corn DDGS had a lower concentration of Lys and higher NDF value than NRC (1998) reported. It is also lower than the data of DDGS from US (Spiehs et al., 2002; Fastinger and Mahan, 2006; Stein et al., 2006). Moreover, different levels of minerals between Chinese and American DDGS have been observed in this experiment. This may be due to the environmental factors during the grain's growth.

\section{Effect of different regions on digestibility of amino acids in corn DDGS}

Many studies have shown various amino acid digestibilities in DDGS sourced from different plants (Fastinger and Mahan, 2006; Stein et al., 2006, 2009). The variation is even greater with Lys because heat damage can have a huge effect on its availability (Cromwell et al., 1993; Pahm et al., 2008). In this study, the average AID and SID value of CP and most amino acids in the 4 corn DDGS were similar to other studies (Widmer et al., 2007; Kim et al., 2009). The AID and SID of amino acids in different DDGS samples varied, and the variation of Lys was observed in this study, which indicated that the digestibility of amino acids in Chinese corn DDGS can also be affected by the region in which the grain was grown. Moreover, in this study, the AID and SID of Lys in Chinese corn DDGS was lower than that in American corn DDGS. The lower Lys to CP ratio of Chinese corn DDGS compared with that of American DDGS (1.93\% vs. 2.87\%), was consistent with a previous study which indicated that the DDGS which contained a high level of Lys had a higher SID value of Lys than DDGS which was low in Lys (Stein, 2007). The low SID value of Lys in Chinese DDGS may also be due to the high fiber content (Urriola et al., 2009).

\section{Ileal amino acids digesitbility of different kinds of DDGS and HP-DDG}

Different resources for DDGS production have a notable impact on amino acid digestibility (Urriola et al., 2009). In this study, the AID and SID of amino acids in rice DDGS were lower than that of corn DDGS samples. These values were also lower than those in other studies on the AID and SID of amino acids in corn DDGS (Fastinger and Mahan, 2006; Stein et al., 2006; Pahm et al., 2008). This may be due to the effect of fermentation on different types of grains. Additionally, the high fiber content in rice DDGS may also lead to a low digestibility of amino acids. This may indicate that rice DDGS has lower amino acid availability than that in corn DDGS. There is little previous research on the nutrient availability of HP-DDG. The HPDDG that was used in the present research contained 38\% CP. The value of AID and SID of amino acids was similar to the data reported by Widmer et al. (2007) and Kim et al. (2009). The AID and SID of amino acids in HP-DDG was higher than that in corn DDGS in this study, which was also consistent with a previous study (Widmer et al., 2007).

\section{DE and ME content in different kinds of DDGS and HP- DDG}

The DE levels of corn DDGS were similar to corn in previous studies (Stein et al., 2006; Pedersen et al., 2007). The ME level of corn DDGS was a little lower than corn in the NRC (1998). This may be a result of high crude fiber levels in corn DDGS, but in this research, the ME level in DDGS was similar to corn, as consistent data reported previously (Pedersen et al., 2007). The DE and ME values of corn DDGS in this experiment were in the range of published data (Spiehs et al., 1999; Fastinger and Mahan, 2006; Stein et al., 2006; Pedersen et al., 2007) and higher than the NRC (1998). However, there is a significant difference of DE and ME levels between the 4 corn DDGS $(p<0.01)$. The DE and ME levels of DDGS from Hebei province (CH3) of China are significantly lower than that of DDGS from Jilin $(\mathrm{CH} 2)$ and US $(\mathrm{p}<0.01)$. It indicates that the region of production also affects the energy value of corn DDGS. The rice DDGS contained a similar gross energy level to corn DDGS, but had lower DE and ME values, though the comparison was not significant. This may indicate that rice DDGS has a lower energy value in swine diets. HP-DDG contained more DE and ME than corn DDGS samples. Moreover, it was reported that feeding $20 \%$, or higher levels of HP-DDG in a complete diet, to growing-finishing pigs did not affect the performance, carcass composition, muscle quality of pigs, or palatability (Widmer et al., 2008). Additionally, Kim et al. (2009) reported that HP-DDG can replace all soybean meal in diets fed to finishing pigs without any impact on growth performance and carcass characteristics. Therefore, HPDDG may be a candidate as a substitute for soybean meal.

In conclusion, from the results of the two experiments, the chemical composition, digestibility of amino acids, DE and ME values in Chinese corn DDGS is similar to American corn DDGS, except for a lower Lys concentration and digestibility. Secondly, the rice DDGS had lower nutrient and digestible amino acids values than corn DDGS. And third, HP-DDG has higher levels of digestible amino acids and energy than DDGS.

\section{REFERENCES}

Adeola, O. 2001. Digestion and balance techniques in pigs. Page 
906 in Swine Nutrition, 2nd ed. A. J. Lewis and L. L. Southern, ed. CRC Press, Washington, DC.

AOAC. 1995. Official methods of analysis. 15th ed. Assoc. Anal. Chem., Arlington, VA.

AOAC. 1998. Official methods of analysis. 16th ed. Assoc. Anal. Chem., Arlington, VA.

Cromwell, G. L., K. L. Herkelman and T. S. Stahly. 1993. Physical, chemical, and nutritional characteristics of distillers dried grains with solubles for chicks and pigs. J. Anim. Sci 71:679686.

Fastinger, N. D. and D. C. Mahan. 2006. Determination of the ileal amino acid and energy digestibilities of corn distillers dried grains with solubles using grower-finisher pigs. J. Anim. Sci. 84:1722-1728.

Kim, B. G., G. I. Petersen, R. B. Hinson, G. L. Allee and H. H. Stein. 2009. Amino acid digestibility and energy concentration in a novel source of high-protein distillers dried grains and their effects on growth performance of pigs. J. Anim. Sci. 87:4013-4021.

NRC. 1998. Nutrient requirement of swine. $10^{\text {th }}$ ed. Nat. Acad. Press, Washington, DC.

Pahm, A. A., C. Pedersen, D. Hoehler and H. H. Stein. 2008 Factors affecting the variability in ileal amino acid digestibility in corn distillers dried grains with solubles fed to growing pigs. J. Anim. Sci. 86:2180-2189.

Pedersen, C., M. G. Boersma and H. H. Stein. 2007. Digestibility of energy and phosphorus in 10 samples of distillers dried grains with solubles fed to growing pigs. J. Anim. Sci. 85:1168-1176.

Renewable Fuels Association. 2010. http://www.ethanolrfa.org/ industry/resources/ coproducts/ Accessed January 3, 2010.

Spiehs, M. J., G. C. Shurson and M. H. Whitney. 1999. Energy, nitrogen, and phosphorus digestibility of growing and finishing swine diets containing distiller's dried grains with solubles. J. Anim. Sci. 77:188 (Suppl. 1).

Spiehs, M. J., M. H. Whitney and G. C. Shurson. 2002. Nutrient database for distiller's dried grains with solubles produced from new ethanol plants in Minnesota and South Dakota. J. Anim. Sci. 80:2639-2645.

Stein, H. H. 2007. Distillers dried grains with solubles (DDGS) in diets fed to swine. Swine Focus \#001. Univ. of Illinois, Urbana-Champaign.
Stein, H. H., B. Sève, M. F. Fuller, P. J. Moughan and C. F. M. de Lange. 2007. Invited review: Amino acid bioavailability and digestibility in pig feed ingredients: Terminology and application. J. Anim. Sci. 85:172-180.

Stein, H. H., C. F. Shipley and R. A. Easter. 1998. Technical note: a technique for inserting a T-cannula into the distal ileum of pregnant sows. J. Anim. Sci. 76:1433-1436.

Stein, H. H., C. Pedersen, M. L. Gibson and M. G. Boersma. 2006. Amino acid and energy digestibility in ten samples of dried distillers grain with solubles by growing pigs. J. Anim. Sci. 84:853-860.

Stein, H. H., S. P. Connot and C. Pedersen. 2009. Energy and nutrient digestibility in four sources of distillers dried grains with solubles produced from corn grown within a narrow geographical area and fed to growing pigs. Asian-Aust. J. Anim. Sci. 22:1016-1025.

Thiex, N. J., H. Manson, S. Anderson and J. Persson. 2002. Determination of crude protein in animal feed, forage, grain, and oilseeds by using block digestion with a copper catalyst and steam distillation into boric acid: collaborative study. J. AOAC Int. 85(2):309-317.

Urriola, P. E., D. Hoehler, C. Pedersen, H. H. Stein and G. C. Shurson. 2009. Amino acid digestibility of distillers dried grains with solubles, produced from sorghum, a sorghum-corn blend, and corn fed to growing pigs. J. Anim. Sci. 87:25742580.

Whitney, M. H. and G. C. Shurson. 2004. Growth performance of nursery pigs fed diets containing increasing levels of corn distiller's dried grains with solubles originating from a modern Midwestern ethanol plant. J. Anim. Sci. 82:122-128.

Whitney, M. H., G. C. Shurson, L. J. Johnston, D. M. Wulf and B. C. Shanks. 2006. Growth performance and carcass characteristics of grower-finisher pigs fed high-quality corn distillers dried grain with solubles originating from a modern Midwestern ethanol plant. J. Anim. Sci. 84:3356-3363.

Widmer, M. R., L. M. McGinnis and H. H. Stein. 2007. Energy, phosphorus, and amino acid digestibility of high-protein distillers dried grains and corn germ fed to growing pigs. J. Anim. Sci. 85:2994-3003.

Zhu, Z. P., R. B. Hinson, L. Ma, D. F. Li and G. L. Allee. 2010. Growth performance of nursery pigs fed $30 \%$ distillers dried grain with solubles (DDGS) and the effects of pelleting on performance and nutrient digestibility. Asian-Aust. J. Anim. Sci. 23:792-798 